\title{
ROLANDO GRIPALDO AND FILIPINO PHILOSOPHY DURING HIS LASALLIAN PERIOD
}

\author{
Feorillo P.A. Demeterio III \\ De La Salle University, Philippines
}

\begin{abstract}
If we are to periodize the intellectual biography of Rolando Gripaldo into his Mindanaoan, Lasallian, and retirement periods, his Lasallian period would be a very significant one because this is the period where he produced the most important works that earned him a niche as one of the important Filipino philosophers. This paper exposed and analyzed the works of Gripaldo in this very significant period of his intellectual biography. This paper was able to identify four clusters of themes that recur in Gripaldo's Lasallian period writings: 1) his reflective thoughts on Filipino philosophy, 2) his studies of Filipino philosophical luminaries, 3) his critical Filipino philosophy, and 3) his efforts towards revisionist writing. This paper contributes towards the discourse of Filipino philosophy that studies Filipino philosophical luminaries, a discourse in which Gripaldo was a leading advocate. Contributions in this specific discourse can make Filipino philosophy more mainstream and easier to study, especially for beginners and undergraduate students.
\end{abstract}

Keywords: Rolando Gripaldo, Filipino philosophy, Filipino philosophical luminaries, critical Filipino philosophy, Filipino philosophy as revisionist writing

\section{INTRODUCTION}

\section{Short Intellectual Biography}

Rolando M. Gripaldo was born in 1948, in Madrid, Surigao del Sur. He finished his bachelor's degree in philosophy at the Mindanao State University, Marawi City, in 1969. Around that time, philosophy in that university was handled by David Wiley, Ross Kales, and Christine Kales, American Peace Corps volunteers, and Leyol Moredo, Juvenal Lazaga, and Ambrosio Quinones, among others. He then joined his professors in that same university. He pursued his graduate studies at the University of the Philippines, Quezon City, where he earned his master's degree in philosophy in 1975. His experiences in that institution shaped his lasting interest in logic and AngloAmerican linguistic philosophy. He earned his doctorate in Philippine studies in that 
same university in 1984, in the fields of history, political science, and philosophy, and with a dissertation on the political and social thought of President Quezon. His decision to pursue a doctorate in Philippine studies instead of pure philosophy definitely shaped his dedication to Filipino philosophy.

Gripaldo continued his career at the Mindanao State University, earned a master's degree in public administration in 1987, and eventually served as the Dean of its College of Social Sciences and Humanities from 1987 to 1991 . He started to explore the brighter opportunities of Metropolitan Manila by working as a history professor at the Ateneo De Manila University, Adamson University, and DLSU. He became a fulltime faculty member of the Philosophy Department of DLSU in 1994. Gripaldo served as President of the Philosophical Association of the Visayas and Mindanao, and the founding Executive Governor of the Philippine National Philosophical Research Society. In 2006, he was granted a visiting research fellowship at the Catholic University of America.

At DLSU, Gripaldo is known for his dedication to Filipino philosophy. Although he wrote in the English language, his textual production dedicated to the development of Filipino philosophy is almost comparable to that of Florentino Timbreza. Tomas Rosario of Ateneo De Manila University, commenting about Gripaldo's monumental project of compiling a bibliography of Filipino philosophy, said: "[ $[\mathrm{H}]$ is continuous research and painstaking gathering of Filipino literature on philosophy is a clear demonstration of his conviction that Filipino consciousness is also philosophical" (Rosario iv). After serving as Chair of the Department of Philosophy for a number of terms, Gripaldo retired from this university as a full professor in 2007. Instead of pursuing a post-retirement career in the academe, he opted to devote his time and energy to the management of the Philippine National Philosophical Research Society, the editorship of this society's biannual journal Philosophia, and this society's monthly philosophical lectures. He died in 2017 from cardiac arrest.

\section{Problematique}

If we are to periodize the intellectual biography of Rolando Gripaldo into his Mindanaoan (c. 1970-c. 1990), Lasallian (c. 1990-2007), and retirement (2008-2017) periods, his Lasallian period would be a very significant one because this is the period where he produced the most important works that earned him a niche as one of the important Filipino philosophers. This paper exposed and analyzed the works of Gripaldo in this very significant period of his intellectual biography. This paper is part of a bigger research project that studied a group of philosophy professors of the De La Salle University who significantly contributed to the development of Filipino philosophy. This bigger research project included Quito, Abulad, Claro Ceniza, and Timbreza in its scope and was generously funded by the University Research Coordination Office of De La Salle University.

\section{Significance}

There are very few publications on Gripaldo's contributions to Filipino 
philosophy. Joaquin’s 2010 article “Gripaldo and Mabaquiao on Filipino Philosophy: A Critical Assessment of Two Attempts to Establish a Filipino Philosophy” compares and contrasts Gripaldo's historical approach and Napoleon Mabaquiao's disciplinal approach in problematizing and talking about Filipino philosophy (Joaquin 2010). Demeterio's 2013 article "Status of and Directions for 'Filipino Philosophy' in Zialcita, Timbreza, Quito, Abulad, Mabaquiao, Gripaldo, and Co," and 2014 article "Assessing the Developmental Potentials of Some Twelve Discourses of Filipino Philosophy," used Gripaldo's reflective thoughts on Filipino philosophy side by side with those of Fernando Zialcita, Timbreza, Emerita Quito, Romualdo Abulad, Mabaquiao, and Alfredo Co, in order to map out a comprehensive schema of the discourses of Filipino philosophy (Demeterio 2013; \& Demeterio 2014a). Demeterio's 2014 article 'Quito, Ceniza, Timbreza, Gripaldo: DLSU Professors' Contributions to Filipino Philosophy" attempted to expose Gripaldo's works on Filipino philosophy in a very limited textual space that is shared with Quito, Ceniza, and Timbreza (Demeterio 2014b). This handful of published works show that there is no full journal article yet that tackled Gripaldo's contributions to Filipino philosophy. This present paper, however, builds on the materials and insights presented in Demeterio's article 'Quito, Ceniza, Timbreza, Gripaldo: DLSU Professors' Contributions to Filipino Philosophy" (Demeterio 2014b). The heavy expository concern of this paper is understanding in the sense that this is the first full journal article on Gripaldo.

From a more general perspective, this paper contributes towards the discourse of Filipino philosophy that studies Filipino philosophical luminaries, a discourse in which Gripaldo was a leading advocate. Contributions in this specific discourse can make Filipino philosophy more mainstream and easier to study, especially for beginners and undergraduate students. From a more specific perspective, this paper can stand as an introduction to the philosophy of Gripaldo, who is definitely one of the important figures of Filipino philosophy.

\section{Methodology}

Data Gathering: During his engagement with DLSU, Gripaldo was able to publish six books: 1) Quezon-Winslow Correspondence and other Essays in 1994, 2) Filipino Philosophy: a Critical Bibliography in 1995, 3) Love and Liberty: the Political and Ethical Philosophy of Emilio Jacinto in 2001, 4) Filipino Philosophy: Traditional Approach, Part I, Section 1 in 2000, 5) Filipino Philosophy: Traditional Approach, Part I, Section 2 in 2004, and 6) The Making of a Filipino Philosopher and other Essays in 2009. In his fourth, fifth, and sixth books, he had the same opportunity that Emerita Quito and Timbreza had to select his best essays and compile them into these volumes on Filipino philosophy. Except for his second book, which is a bibliographic listing, this paper analyzes all his books that he produced while being a professor at DLSU. It should be noted that the sixth book, although published two years after his retirement, actually contains essays from his last years of engagement with the said university.

The book Quezon-Winslow Correspondence and other Essays contains 12 essays: 1) "The Quezon-Winslow Correspondence: a Friendship Turned Sour," 2) 
"The Quezon-Osmena Split of 1922," 3) "The Quezon-Wood Controversy," 4) "Quezon and the Fairfield Project," 5) "Quezon and Osmena on the Hare-HawesCutting and Tydings-McDuffie Acts," 6) "Quezon on the Dominion Status for the Philippines," 7) "Social Justice: Cornerstone of Quezon's Social Thought," 8) "Quezon's Partyless Democracy," 9) "Quezon's Philosophy of Philippine Education," 10) "Quezon on the Question of Reelection," 11) "Presidential Succession of 1943," 12) "Quezon's Political and Social Thought: a Dissertation Resume."

The book Love and Liberty: the Political and Ethical Philosophy of Emilio Jacinto is a monograph on the thoughts and insights of the said national hero.

The book Filipino Philosophy: Traditional Approach, Part I, Section 1, contains 12 essays: 1) "Laurel: the Political Philosopher and the Man" of 1982, 2) "Rizal's Philosophy of Nonviolence" of 1986, 3) "Bonifacio, the Translator: a Critique" of 1987, 4) "Quezon's Political Philosophy" of 1992, 5) "Reflections of Bonifacio's Philosophy of Revolution” of 1992, 6) "Social Justice: Cornerstone of Quezon's Social Thought” of 1994, 7) “Jacinto's Libertarian Philosophy of Revolution” of 1996, 8) "Rizal's Utopian Society" of 1996, 9) "Bonifacio and Jacinto: Two Philosophies of Revolution and their Sources" of 1997, 10) "Agnostic Deism: Rizal's Religious Philosophy" of 1998, 11) "Quezon's Philosophy of Philippine Education" of 1998, and 12) "Renato Constantino's Philosophy of Nationalism: a Critique" of 1999.

The book Filipino Philosophy: Traditional Approach, Part I, Section 2, contains 11 main essays: 1) "Freedom and Futurism in Art: a Critique of Embuscado's Aesthetics of Dissectionism" of 2001, 2) "The Ideal Poem as the Rubber Tower: a Hermeneutical Analysis of Cirilo Bautista's Theory on the Poem" of 2002, 3 ) "Ceniza the Neo-Parmenidean: a Critique of his Metaphysics" of 2004, 4) "Freedom to Choose: An Essay on Situational Determinism" of 2003, 5) "He Could Have Chosen Otherwise?" of 1977, 6) "Media Powerhouse: Challenges to Contemporary Philosophers" of 2005, 7) "Tourism and Heritage in a Global Society: the Philippine Experience" of 2005, 8) "Cultural Approach to Filipino Philosophy" of 2003, 9) "Cultural Traditions, the Person, and Contemporary Change: the Filipino Experience" of 2001, 10) "The Person as Individual and Social Being," of 2003, and 11) "The Person, the Nation, and the World: Cooperative Choice in a Globalizing Situation," of 2007.

The book The Making of a Filipino Philosopher and other Essays contains five essays: 1) "Is there a Filipino Philosophy?" of 2003, 2) "Filipino Philosophy: a Western Tradition in an Eastern Setting" of 2006, 3) "Filipino Philosophy, Western Tradition, and Nation Building" of 2006, 4) "The Concept of the Public Good: a View from a Filipino Philosopher" of 2006, and 5) "The Making of a Filipino Philosopher" of 2007.

Interpretive Framework: the interpretive framework used by this paper is the schematization of Filipino philosophy into twelve discourses that was first laid down by Demeterio's 2013 article "Status of and Directions for 'Filipino Philosophy' in Zialcita, Timbreza, Quito, Abulad, Mabaquiao, Gripaldo, and Co," and refined in his 2014 article "Assessing the Developmental Potentials of Some Twelve Discourses of Filipino Philosophy" (Demeterio 2013; \& Demeterio 2014a). These twelve discourses of Filipino philosophy are 1) Filipino philosophy as the exposition of foreign systems; 
2) Filipino philosophy as the application of logical analysis; 3) Filipino philosophy as the application of phenomenology and hermeneutics; 4) Filipino philosophy as the appropriation of foreign theories; 5) Filipino philosophy as revisionist writing; 6) Filipino philosophy as academic critical analysis; 7) Filipino philosophy as the interpretation of the Filipino worldview; 8) Filipino philosophy as research on Filipino ethics and values; 9) Filipino philosophy as the appropriation of folk spirit; 10) Filipino philosophy as the study on the presuppositions and implications of the Filipino worldview; 11) Filipino philosophy as the study of the Filipino philosophical luminaries; and 12) Filipino philosophy in the Filipino language (Demeterio 2014a, 191-192).

Recurrent Discourses of Filipino Philosophy in Gripaldo's Lasallian Period: Following Leslie Anne Liwanag's system of classification for the works of Quito, the following table (see table 1) classifies the 41 works of Gripaldo against the twelve discourses of Filipino philosophy of Demeterio (Cf. Liwanag 2016, 66-67).

Table 1

Classification of Gripaldo's works

\begin{tabular}{|l|l|c|c|}
\hline Taxonomy & \multicolumn{1}{|c|}{ Title } & $\begin{array}{c}\text { Number } \\
\text { of } \\
\text { Works }\end{array}$ & $\begin{array}{c}\text { Percen } \\
\text { tage }\end{array}$ \\
\hline $\begin{array}{l}\text { Logical } \\
\text { Analysis }\end{array}$ & & 0 & $0.0 \%$ \\
\hline $\begin{array}{l}\text { Phenomenolog } \\
\text { Existentialism / } \\
\text { Hermeneutics }\end{array}$ & & 0 & $0.0 \%$ \\
\hline & $\begin{array}{l}\text { "Media Powerhouse: Challenges to Contemporary } \\
\text { Philosophers," "Tourism and Heritage in a Global } \\
\text { Society: the Philippine Experience," "Cultural } \\
\text { Approach to Filipino Philosophy," "Cultural } \\
\text { Traditions, the Person, and Contemporary Change: } \\
\text { the Filipino Experience," "Is there a Filipino } \\
\text { Philosophy?," "Filipino Philosophy: a Western } \\
\text { Tradition in an Eastern Setting," "Filipino } \\
\text { Philosophy, Western Tradition, and Nation }\end{array}$ & & \\
Philosophy & $\begin{array}{l}\text { Building," "The Making of a Filipino Philosopher," } \\
\text { "Quezon on the Dominion Status for the } \\
\text { Philippines," "Social Justice: Cornerstone of } \\
\text { Quezon's Social Thought," "Quezon's Partyless } \\
\text { Democracy," "Quezon's Philosophy of Philippine } \\
\text { Education," "Quezon's Political and Social } \\
\text { Thought: a Dissertation Resume," "Love and } \\
\text { Liberty: the Political and Ethical Philosophy of } \\
\text { Emilio Jacinto," "Laurel: the Political Philosopher } \\
\text { and the Man," "Rizal's Philosophy of } \\
\text { Nonviolence," "Bonifacio, the Translator: a }\end{array}$ & 27 & $65.9 \%$ \\
\hline
\end{tabular}




\begin{tabular}{|c|c|c|c|}
\hline & $\begin{array}{l}\text { Critique," "Quezon's Political Philosophy," } \\
\text { "Reflections of Bonifacio's Philosophy of } \\
\text { Revolution," "'Social Justice: Cornerstone of } \\
\text { Quezon's Social Thought," "Jacinto's Libertarian } \\
\text { Philosophy of Revolution," "Rizal's Utopian } \\
\text { Society," "Bonifacio and Jacinto: Two Philosophies } \\
\text { of Revolution and their Sources," "Quezon's } \\
\text { Philosophy of Philippine Education," "Renato } \\
\text { Constantino's Philosophy of Nationalism: a } \\
\text { Critique," "The Person as Individual and Social } \\
\text { Being," and "The Person, the Nation and the } \\
\text { World: Cooperative Choice in a Globalizing } \\
\text { Situation" }\end{array}$ & & \\
\hline $\begin{array}{l}\text { Appropriation } \\
\text { of Foreign } \\
\text { Theories }\end{array}$ & & 0 & $0.0 \%$ \\
\hline $\begin{array}{l}\text { Appropriation } \\
\text { of Folk } \\
\text { Philosophy }\end{array}$ & & 0 & $0.0 \%$ \\
\hline $\begin{array}{l}\text { Philosophizing } \\
\text { using the } \\
\text { Filipino } \\
\text { Language }\end{array}$ & & 0 & $0.0 \%$ \\
\hline $\begin{array}{l}\text { Exposition of } \\
\text { Foreign } \\
\text { Systems }\end{array}$ & & 0 & $0.0 \%$ \\
\hline $\begin{array}{l}\text { Revisionist } \\
\text { Writing }\end{array}$ & $\begin{array}{l}\text { "Freedom to Choose: An Essay on Situational } \\
\text { Determinism," "He Could Have Chosen } \\
\text { Otherwise?," and "The Concept of the Public } \\
\text { Good: a View from a Filipino Philosopher" }\end{array}$ & 3 & $7.3 \%$ \\
\hline $\begin{array}{l}\text { Interpretation } \\
\text { of Filipino } \\
\text { Worldview }\end{array}$ & & 0 & $0.0 \%$ \\
\hline $\begin{array}{l}\text { Research on } \\
\text { Filipino values } \\
\text { and Ethics } \\
\end{array}$ & & 0 & $0.0 \%$ \\
\hline $\begin{array}{l}\text { Identification of } \\
\text { the } \\
\text { Presuppositions } \\
\text { \& Implications } \\
\text { of the Filipino } \\
\text { Worldview }\end{array}$ & & 0 & $0.0 \%$ \\
\hline $\begin{array}{l}\text { Study on the } \\
\text { Filipino } \\
\text { Philosophical } \\
\text { Luminaries }\end{array}$ & $\begin{array}{l}\text { "The Quezon-Winslow Correspondence: a } \\
\text { Friendship Turned Sour," "The Quezon-Osmena } \\
\text { Split of 1922," "The Quezon-Wood Controversy," } \\
\text { "Quezon and the Fairfield Project," "Quezon and } \\
\text { Osmena on the Hare-Hawes-Cutting and Tydings- } \\
\text { McDuffie Acts," "Quezon on the Question of } \\
\text { Reelection," "Presidential Succession of 1943," } \\
\text { "Agnostic Deism: Rizal's Religious Philosophy," }\end{array}$ & 28 & $68.3 \%$ \\
\hline
\end{tabular}




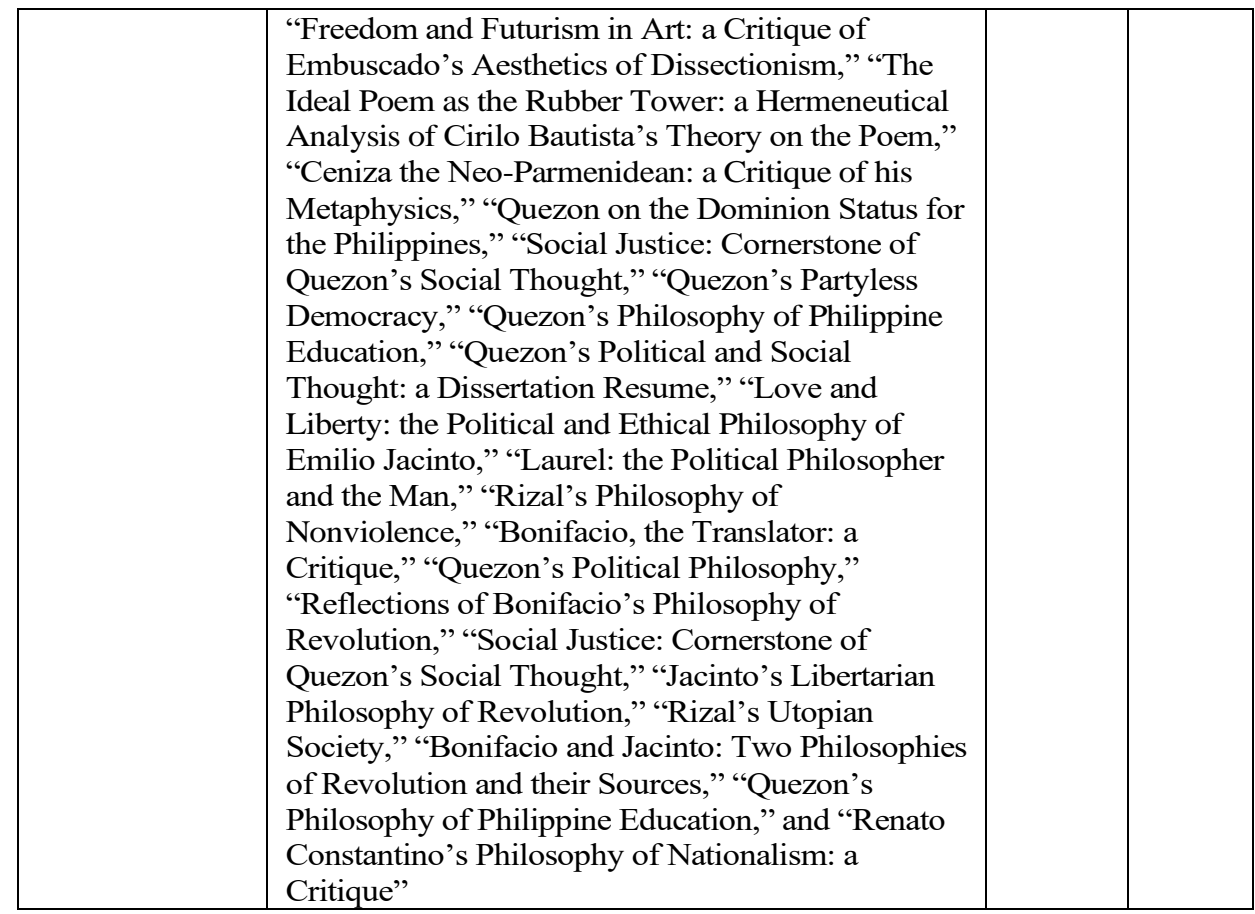

The classification in Table 1 can be further illustrated using the following radar chart (see fig. 1):

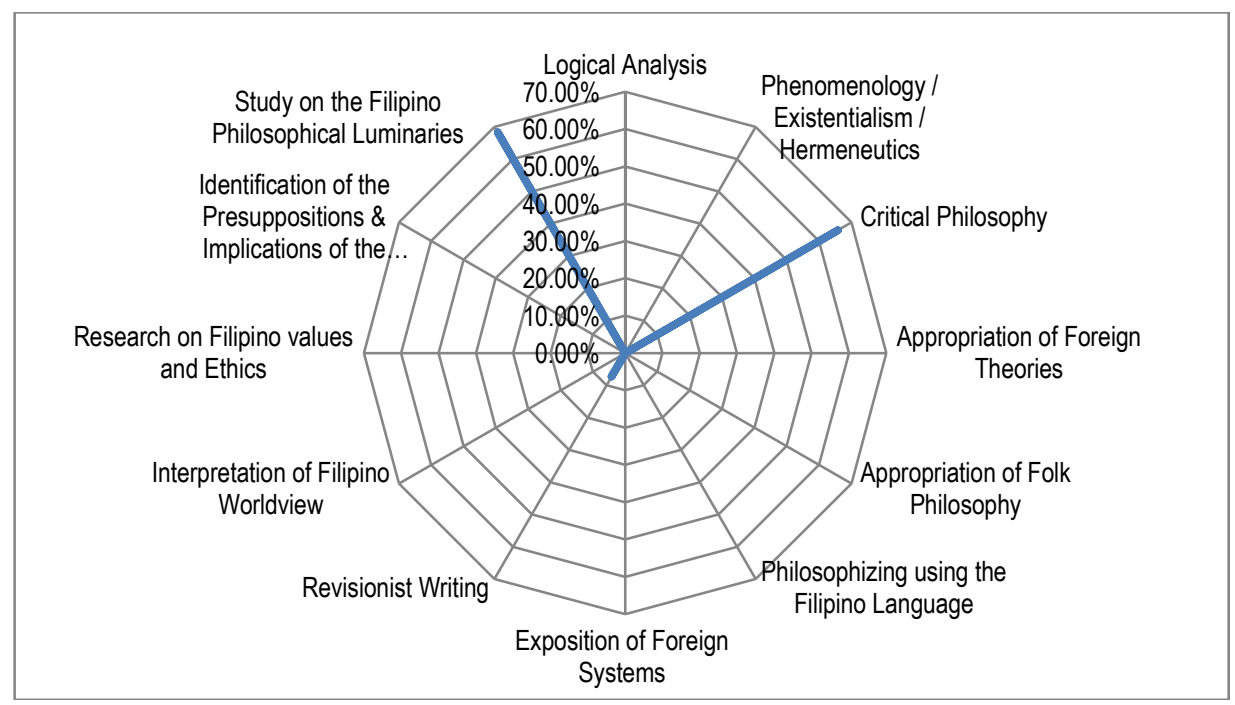

Figure 1. Radar chart showing the classification of Gripaldo's works 
Organization of this Paper: Based on table 1 and figure 1, Gripaldo's works are concentrated on: the study of Filipino philosophical luminaries $(68.3 \%)$ and critical Filipino philosophy (65.9\%). This paper has two substantive sections. The first one explored Gripaldo's reflective thoughts on Filipino philosophy, while the second one undertook a more detailed look into his studies of Filipino philosophical luminaries, as well as into his critical Filipino philosophy.

\section{REFLECTIVE THOUGHTS ON FILIPINO PHILOSOPHY}

Gripaldo's reflective thoughts on the nature of Filipino philosophy may be divided into his identification of the hindrances for the development of Filipino philosophy, his critique of Filipino philosophy as the interpretation of Filipino identity and worldview, and his proposed developmental path for Filipino philosophy.

\section{Hindrances for Filipino Philosophy}

Gripaldo's identification of the elements and factors that hindered the development of Filipino philosophy is primarily found in the essays "Filipino Philosophy, Western Tradition, and Nation Building" (2006) and "The Making of a Filipino Philosopher" (2007). The first of these elements and factors is the widespread misconception of Filipinos on what philosophy is. In the present setup, colleges and universities are only required by the Commission on Higher Education to offer one philosophy course to students not majoring in philosophy, and this single philosophy course is usually devoted to logic, or philosophy of man or ethics. Thus, Filipino graduates tend to narrowly define philosophy in accordance with that single philosophy course that they took up in college (Cf. Gripaldo, "Filipino Philosophy, Western Tradition, and Nation Building" 44). Those few Filipinos who majored in philosophy are not necessarily better off because they would most probably be trained in a particular philosophical tradition, such as Thomism/Scholasticism, AngloAmerican linguistic philosophy, or contemporary continental European philosophy. Thus, they would, in the end, also narrowly define philosophy in accordance to that tradition where they get their academic training (Cf. Gripaldo, "Filipino Philosophy, Western Tradition, and Nation Building" 45). Gripaldo claimed that the Filipinos' failure to conceptualize philosophy as a discipline - as they are mired in the idea that it is just logic, philosophy of man, or ethics, or in the idea that it is just a particular tradition-could surely hinder the development of Filipino philosophy.

The second element and factor mentioned by Gripaldo are similar to Quito's third reason for the underdevelopment of Filipino philosophy, which has something to do with the limited career opportunities offered by philosophy as a terminal degree program. If philosophy in the Philippines could not attract the best and the brightest students, Gripaldo pointed out that it really would have developmental problems, as philosophical speculations could not effectively prosper if whom we have are second or third class specialists in philosophy (Cf. Gripaldo, "Filipino Philosophy, Western Tradition, and Nation Building" 46-48). The third of these elements and factors is Filipino philosophy's western orientation and its failure to dialogue with its own local 
and native tradition. Our western orientation entraps us in a state of just being a philosophical scholar of a given foreign system. Gripaldo argued that no matter how good a philosophical scholar a certain Filipino would be, this would not be a guarantee that he would mature into a true philosopher (49-50). Our failure to dialogue with our own local and native philosophical tradition gave us the disadvantage of not being aware of the philosophical questions that historically had been relevant to us as a nation. Unlike Quito, who believed that the Filipinos do not have a philosophy in the strict sense of the word, Gripaldo was a staunch advocate of the idea that Filipinos have their own philosophies, and these can be gleaned in the writings of our intellectuals, who may not be academic philosophers or doctors of philosophy.

Gripaldo's fourth element and factor is very much related to the third one in the sense that our infatuation with western philosophies and our failure to root ourselves in our own philosophical tradition has given us philosophical activities that are devoid of direction. Gripaldo stressed that Filipino philosophy should be utilized for the project of nation-building by helping in the intellectual formation of our professionals and by helping in the bigger project of enriching our intellectual heritage (Cf. Gripaldo, "Filipino Philosophy, Western Tradition, and Nation Building" 51-52). The fifth of these elements and factors is the Filipinos' easy and contended life and lack of drive for professional excellence (Cf. Gripaldo, "The Making of a Filipino Philosopher" 67). Gripaldo noted that the majority of Filipino academicians in philosophy who finished their master's or doctor's degrees were no longer motivated to pursue further research. Even rigorous scholarship in philosophy, which for Gripaldo is clearly inferior to real philosophizing, would suffer from this way of life. Gripaldo's sixth element and factor focused on the deficiencies of the philosophical organizations in the Philippines that failed to unite under one umbrella organization, to foster research and publication, and to be developmental in their outlook (68-69).

\section{Critique of Filipino Philosophy as the Interpretation of Filipino Identity and Worldview}

Gripaldo's critique of Filipino philosophy as the interpretation of Filipino identity and worldview is mainly found in the essays "Cultural Approach to Filipino Philosophy" (2003), "Is there a Filipino Philosophy?" (2003), and "The Making of a Filipino Philosopher" (2007). According to him, Filipino philosophy as the interpretation of Filipino identity and worldview refers to that project that started in the 1970s on the extraction of philosophical insights from anthropological data, such as folk sayings, folk lore, songs, and other popular practices (cf. Gripaldo, "Cultural Approach to Filipino Philosophy" 173). He named Leonardo Mercado and Timbreza as the main proponents of this approach in Filipino philosophy. He then traced the emergence of this approach in Filipino philosophy back to a style of philosophizing that was initiated by the Yale University sociologist and anthropologist William Graham Sumner (1840-1910), who in his 1907 book Folkways: a Study of the Sociological Importance of Usages, Manners, Customs, Mores, and Morals made the assertion that cultural folkways and mores are the product of a given society's adaptation for survival and they may only be changed through the presence of new 
challenges and through the manipulations of some elite and powerful group. Sumner was suggesting that folkways and mores should be considered more important to philosophies and morals because they are actually the philosophies and morals of a given society.

Although Gripaldo affirmed the discursive significance of this kind of Filipino philosophy as it is geared towards the articulation and understanding of the Filipino folkways/folk philosophies and mores/morals, he warned the Filipino scholars who intend to focus on this area of philosophizing that they should not duplicate the theoretical error committed by Sumner. Gripaldo stressed that Sumner, in effect, had argued that the "is" should also be the "ought" in his attempt to respect the radical autonomy of a given society. In other words, Filipino scholars who work in the parameters of Filipino philosophy as the interpretation of Filipino identity and worldview should not stop with the mere articulation and description of the Filipino folkways and mores but should exert further efforts in making their findings useful and in critiquing and rectifying whatever folkways and mores they have established to be counterproductive and questionable. Gripaldo stressed: "[T]he end of understanding such a worldview must be to cleanse it of impurities, so to speak, in order to improve or better society and to enrich the nation's cultural heritage" ("Cultural Approach to Filipino Philosophy" 177).

\section{Developmental Path of Filipino Philosophy}

Gripaldo's suggested developmental path for Filipino philosophy is mainly contained in the essays "Is there a Filipino Philosophy?" (2003), "Filipino Philosophy, Western Tradition, and Nation Building" (2006), and "The Making of a Filipino Philosopher" (2007). This developmental path is actually constituted by the remedies recommended for the hindrances that he already uncovered and itemized. Hence, the first of these remedies is the attainment of a more functional definition of what philosophy is, which for him can be done by properly conceptualizing philosophy as a discipline. He lauded the innovation introduced by Quito in the Philosophy Department of DLSU that made this department eclectic in its outlook (Cf. Gripaldo, "Filipino Philosophy, Western Tradition, and Nation Building" 46). Gripaldo was convinced that this eclecticism has the potency of presenting a fuller picture of what philosophy really is. Gripaldo did not lay out a proposal in counteracting the widespread perception about the absence of career opportunities for philosophy graduates. But he did present a thorough argumentation that such perception is baseless as philosophy is an effective training ground for a career in research firms, business firms, and publishing companies, or for further studies in law and other graduate programs (Cf. Gripaldo, “The Making of a Filipino Philosopher” 47).

Gripaldo's second remedy is his emphasis that Filipino philosophy should tone down its western orientation by focusing on its own philosophical tradition (Cf. Gripaldo, "The Making of a Filipino Philosopher" 69-70). With his desire to educate the younger generations of Filipino specialists in philosophy in our own philosophical tradition, he devoted much of his academic career to extracting and re-articulating the philosophical insights of many of our Filipino intellectuals. His third remedy is his 
recommendation that philosophizing should be done for the service of nation-building (Cf. Gripaldo, "Filipino Philosophy, Western Tradition, and Nation Building" 58). Gripaldo is not saying here that Filipino philosophy should interface with nationalistic ideology to the point that Filipino philosophers would be reduced to the status of patriotic demagogues. On the contrary, he is merely saying that philosophizing should be done with the purview of strengthening the intellectual capital of our youth and citizens and consolidating and enriching further our intellectual heritage as a nation (Gripaldo, "Filipino Philosophy, Western Tradition, and Nation Building" 58).

Gripaldo's fourth remedy is his challenge to Filipino academicians in philosophy to devote themselves to research and publication continuously. He even remained open to the possibility that many Filipino academicians would opt to dedicate their careers to the scholarship of specific foreign thinkers. However, he advised these academicians not to stop at the point when they have already mastered the biography, works, and theories of the foreign philosopher of their choice, for there is always that possibility that they can create philosophy breakthroughs by going beyond the doctrines of their selected thinkers. He advised: "[D]epart from just being an expert or a scholar . . . but . . . modify those ideas in a uniquely original way such that one ceases to be, e.g., simply a Kantian, but becomes a neo-Kantian" (Gripaldo, "Is there a Filipino Philosophy" 5). His fifth remedy revolved around the restructuring, consolidation, and re-orientation of the philosophical organizations of the country. He wanted these scattered organizations to have an umbrella organization like what is practiced in many countries abroad, to go beyond their current focus on hosting seminars and conferences and foster the culture of research and publication, and to eventually become institutional members of the International Federation of Philosophical Societies (Cf. Gripaldo, "Filipino Philosophy, Western Tradition, and Nation Building" 53-55). Gripaldo underscored the ego-centricism and selfishness of many Filipino philosophy professors that limited their view of philosophy as personal and individual toil and blinded them to the prospect that Filipino philosophy will greatly benefit from the mutual cooperation of individual Filipino scholars and organizations (Gripaldo, "Filipino Philosophy, Western Tradition, and Nation Building” 58).

\section{SUBSTANTIVE THOUGHTS ON FILIPINO PHILOSOPHY}

As already mentioned, this section on the substantive thoughts of Gripaldo on Filipino philosophy discusses the thrust of his philosophizing as revealed by table 1 and figure 1. Hence, the following sub-sections tackle his studies of Filipino philosophical luminaries, critical Filipino philosophy, revisionist writing, and appropriation of foreign theories.

\section{Filipino Philosophy as the Study of Filipino Philosophical Luminaries}

The bulk of Gripaldo's philosophizing is focused on the interpretation of the philosophical insights of a number of Filipino intellectuals. This sub-section, however, will limit these intellectuals to the national heroes Jose Rizal and Andres Bonifacio, 
the Philippine Presidents Manuel Quezon and Jose Laurel (1891-1959), the historian Renato Constantino (1919-1999), and the just recently recognized National Artist for literature Cirilo Bautista (born: 1941).

On Jose Rizal: Gripaldo's discussion on the philosophical insights of Rizal is contained in the essays "Rizal's Philosophy of Nonviolence" (1986), "Rizal's Utopian Society" (1996), and "Agnostic Deism: Rizal's Religious Philosophy” (1998). As hinted by the titles of these essays, Gripaldo focused his attention on the extraction of Rizal's philosophical thoughts on nonviolence, his utopian vision, and his theodicy.

Rizal's philosophy of nonviolence is rooted in his notion of freedom, which according to Gripaldo, is the condition that allows man to attain his full potentialities (Cf. Gripaldo, "Rizal's Philosophy of Nonviolence" 13). This is the reason why, for Rizal, there seemed to be no contradiction between freedom and the full integration of the Philippines as a true province of Spain. At that time, the Philippines' being a mere colony meant that it was not accorded substantial rights; hence, the individual freedom of the Filipinos was trampled upon by the Spanish officials and the elite principalia. However, if the Philippines, or the patria chica, would become a true province of Spain, or the patria grande, just like the other Spanish provinces, or patrias chicas, of Catalonia, Vizcaya, Galicia, and Andalucia, it would be accorded with rights and privileges that sooner or later would assure every Filipino the chance of attaining his/her full potentialities. This was the mindset of Rizal when he sailed to Spain and joined the propaganda movement (Gripaldo, "Rizal's Philosophy of Nonviolence" 10). For him, a bloody and violent revolution was not necessary, especially if the people who were expected to overthrow the colonial power were largely uneducated and unenlightened. If in case this bloody and violent revolution would prosper and succeed, the uneducated and un-enlightened masses would only replace the vacuum that would be left behind by the colonizers, and they would only become even worse tyrants. Hence, education and enlightenment were more important than revolution for Rizal. But as history unfolded in front of him, Rizal realized that his philosophy of nonviolence was inadequate, and he was soon overtaken by feelings of vengeance against the colonizers and the desire of the Filipino for real political freedom.

Gripaldo attempted to extract Rizal's utopian society from his visions and desires for the Philippine country. Gripaldo listed down six characteristics of Rizal's utopia. First, "the Philippine archipelago must be united as a Filipino nation: compact, vigorous, and homogeneous" (Gripaldo, "Rizal's Utopian Society" 27). Second, the Filipinos will have sound education about civic virtues that would lead them to enlightenment so that each and every one of them will be capable of fighting slavery and injustice and working for their individual and collective good. Third, the country will have sufficient schools that would be effective in molding the Filipino youth humanistically, professionally, and vocationally. Fourth, the Filipinos will have a national language that is based on one of their native languages that will unite the Filipinos and sufficiently articulate their aspirations. Fifth, the state will guarantee that all Filipinos will have their liberties, such as "freedom of speech, of assembly, of the press, redress of grievances, and the enjoyment of other human rights" (Gripaldo, "Rizal's Utopian Society" 27). Sixth, the Filipinos will have a strong sense of nationalism. 
Gripaldo called Rizal's theodicy, or religious philosophy, "agnostic deism," in the sense that Rizal believed in a "God who does not interfere in man's affairs and whose attributes are unknowable" (Gripaldo, "Agnostic Deism" 52). About the human soul and its immortality, Gripaldo expounded on Rizal's almost Pythagorean and Platonic utterance that God shared with man a spark of His divinity and arrived at the conclusion that Rizal believed in the existence of the human soul and its continued existence after death (Gripaldo, "Agnostic Deism" 53). Gripaldo regretted that Rizal did not reflect much on the problem of evil, which is supposed to be one of the central topics of theodicy.

On Andres Bonifacio: Gripaldo's discussion on the philosophical insights of Bonifacio is contained in the essays "Bonifacio, the Translator: a Critique" (1987), "Reflections on Bonifacio's Philosophy of Revolution" (1992), and "Bonifacio and Jacinto: Two Philosophies of Revolution and their Sources" (1997). His study on Bonifacio focused on the latter's philosophy of revolution, which the former outlined in six points. First, Bonifacio conceptualized the Spanish colonization as a contract between the Spaniards and the Indios in which the former promised to look after the welfare of the latter for the consideration of the latter's agreement that the former occupy their homeland (Cf. Gripaldo, "Reflections on Bonifacio's Philosophy of Revolution" 73). Then, Bonifacio pointed out that the Spaniards committed a breach of contract in the sense that they did not fulfill their obligation of looking after the welfare of the Indios. Instead, the Spaniards even persecuted the Indios, who aired their sentiments about the Spanish shortcoming. Bonifacio concluded that a revolution was necessary to put an end to the contract, which the Spaniards were not willing to respect in the first place. Second, Bonifacio was aware that to lead a revolution meant to agitate the people against the colonizers. His strategy was to work on the Tagalog people first and consolidate their support for the Katipunan (Gripaldo, "Reflections on Bonifacio's Philosophy of Revolution" 74-75). He expected that other individuals from other ethnic groups would do the same thing to their people. Instead of spreading himself thinly to cover all the ethnic groups of the whole country, he decided to concentrate on his own people and just wait for the ripple effects of his efforts.

Third, Gripaldo argued that Bonifacio, although he was poor and uneducated, was, in fact, an ilustrado in the sense that he attained enlightenment through his own readings and political involvement. Gripaldo clarified that the term "ilustrado" is not primarily a socio-economic category but a category that pertains to the accumulation of intellectual and cultural capitals. There were many other richer Filipinos at that time who had the privilege of going to a university but who never attained enlightenment (Cf. Gripaldo, "Reflections on Bonifacio's Philosophy of Revolution" 75-76). Fourth, Gripaldo laid down his findings that Bonifacio's revolution might not exactly be a revolution from below as popularized by such eminent historians as Teodoro Agoncillo (1912-1985) and Reynaldo Ileto (born: 1946) because Bonifacio could not be easily categorized as a typical lower-class Filipino due to his considerable intellectual and cultural capital, and because many of the leading Katipuneros were actually members of the middle class. Hence, Gripaldo claimed that the revolution was a movement that was actually led and organized by some middle-class and maybe 
lower-middle-class freedom fighters (Gripaldo, “Reflections on Bonifacio's Philosophy of Revolution" 76-77).

Fifth, when Bonifacio agitated the people to rise up against their colonizers, he mentioned the abuses and misgovernance that they suffered at the hands of the Spaniards, but he also made it a point that the people would be animated with the utopia that would serve as the gleaming beacon of their struggles and sacrifices. Bonifacio's utopia was the lost Eden, the pristine and bustling Filipino societies that existed prior to the coming of the rapacious Spaniards (Cf. Gripaldo, "Reflections on Bonifacio's Philosophy of Revolution" 77-78). This lost Eden could only be regained by driving the colonizers away. Gripaldo agreed with Ileto that Bonifacio casted his utopia in the language of the pasyon in order to reach the hearts of more Tagalogs who were familiar with this Lenten text. Sixth, Bonifacio liberally used history and his ability to write poems and to translate some works of Rizal in order to attain his end of agitating and animating the Tagalogs to his cause. In the essay "Bonifacio, the Translator: a Critique," Gripaldo demonstrated that Bonifacio's supposedly bad translation of Rizal's "Mi Ultimo Adios" was actually a strategic praxis of bringing the poem of Rizal closer to the hearts of the Tagalogs (Cf. Gripaldo, "Bonifacio, the Translator" 62-71).

On Manuel Quezon: Gripaldo wrote his dissertation on Quezon and published a portion of it as his book Quezon-Winslow Correspondence and other Essays, but our short presentation of his extraction of Quezon's political philosophy is based on the essays "Quezon's Political Philosophy" (1992), "Social Justice: Cornerstone of Quezon's Social Thought" (1994), and "Quezon's Philosophy of Philippine Education" (1998). Gripaldo focused on what he claimed to be Quezon's double stranded political philosophy, the first one of which pertained to the latter's political strategy, while the second one to the latter's substantive theorizing that was geared towards the preparation of the country for its eventual independence from the United States of America.

Gripaldo called the strategic strand of Quezon's political philosophy “political pragmatism." The former defined this as the conviction that "one should fight for ideals and principles, but in case obstacles to an ideal are difficult to surmount, one must be ready to fall back on an alternative that is better than nothing or that is a right step toward the ideal" (Gripaldo, "Quezon's Political Philosophy" 113). According to Gripaldo, Quezon used this strategy in working out a roadmap that would eventually lead to Philippine independence, which at the same time contained milestones that were palatable to both the American officials and the Filipino public.

The second strand of Quezon's political philosophy is more complex in the sense that it dealt with the more detailed plan on how to make the Filipinos and the youthful Filipino government ready for the tremendous responsibilities of an independent nation-state (Cf. Gripaldo, “Quezon's Political Philosophy” 122-140). Quezon saw a number of threats that could disable such independence from the very start, such as the imperialist ambitions of Japan, the political immaturity of the Filipinos, the possible abuses of the elite Filipinos on the unfortunate masses, and the weak pre-modern character of the masses. 
The most interesting aspect of the second strand of Quezon's political philosophy is probably his critique of the weakness of the Filipino character, which led him to formulate a code of ethics/conduct that he thought could rectify such defective character. Gripaldo writes:

Quezon noticed that the Filipinos lacked earnestness; were not inclined to sustain hard effort; were frivolous and inconstant; lacked perseverance; had only skin-deep patriotism; valued face-saving very much; were desirous of personal gain which dulled their sense of righteousness; valued expediency in their norm of conduct rather than principle; showed a 'failing in that superb courage which impels action because it is right, even at the cost of self-sacrifice'; had as their greatest fear, not the act to do wrong, but of 'being caught doing wrong'; took religion lightly; easily accepted defeat, and were apt to compromise with ethical principles and to regard truth as compatible with misrepresentation or self-deceit. (“Quezon's Philosophy of Philippine Education” 169)

If we as a people are not ready to accept these weaknesses that also weakened our nation, then we will never be ready for any serious effort in systematically correcting these shortcomings.

Because Quezon was bold and sharp enough to tell the Filipino straight to his face that there was something wrong with his soul, he earned the right to lay down his prescription, which he did in the form of a code of ethics/conduct. According to Gripaldo, this code contains sixteen items that every Filipino should learn and master by heart: 1) faith in God, 2) unconditional love for the country, 3) respect for the constitution and the government, 4) proper payment of taxes, 5) commitment to the sanctity of elections, 6) love and respect for the parents, 7) valorization of one's honor, 8) truthfulness, justice, and charity, 9) clean and frugal life, 10) commitment to emulate the virtues of our heroes, 11) industry, 12) self-reliance and the tenacious pursuit of one's legitimate ambitions, 13) love for one's work, 14) promotion of social justice, 15) dedication to buy Filipino products, and 16) wise use of our natural resources and vigilance against the exploitation of fellow Filipinos (cf. Gripaldo, “Quezon's Philosophy of Philippine Education" 169).

On Jose Laurel: Gripaldo's extraction of the political philosophy of Laurel is contained in the 1982 essay "Laurel: the Political Philosopher and the Man." Gripaldo premised his reflection on Laurel's political thoughts on an explanation that the accusation of the other historians concerning the latter's collaboration with the Japanese should be properly contextualized as the latter's obedience to the parting orders of Quezon that he stay behind and help take care of the country (Cf. Gripaldo, "Laurel" 186-187). Before the Japanese occupation, Laurel had a number of Japanese clients who opened businesses in Mindanao, and he had been given an honorary doctor's degree by the University of Tokyo. This made Quezon believe that he could be a good intermediary between the Filipino people and the invading Japanese forces. Gripaldo argued that Laurel's efforts in running a provisional government under the 
Japanese flag were done in good faith. In fact, in the essay "Cultural Traditions, the Person, and Contemporary Change: the Filipino Experience," Gripaldo depicted Laurel as a good padrino who protected a number of Filipinos against the violence of the Japanese Kempeitai (Cf. "Cultural Traditions, the Person, and Contemporary Change" 190-191).

The main points of Laurel's political philosophy were focused on his reflection on law and democracy. Human beings and nations are analogous in the sense that they need other human beings and other nations to continue their healthy existence. However, such a need also entails difficulties in the day-to-day dealing with other human beings or nations. The love-hate relationship between human beings and between nations needs to be regulated by laws (Cf. Gripaldo, "Laurel" 174). These laws, for practical considerations, embody the ethics, morality, and the sense of justice and goodness of a given community of individuals or nations. In the case of the community of individuals, Laurel stressed that laws should strike a good balance between government control and individual liberties because the predominance of the former would result in a tyrannical government, while the predominance of the latter would result in an anarchical society (Gripaldo, "Laurel" 175).

Gripaldo claimed that, for Laurel, the functional model of democracy for the Philippines is representative republicanism (Cf. Gripaldo, "Laurel" 175). In this model, the people remain sovereign, even if they delegate their power to some elected representatives. These elected representatives, together with their appointed executives, career officers, and employees, would assure the people that the government would provide the sovereign people with sufficient chances for livelihood, health, social justice, and educational programs, as well as with an environment of economic opportunities.

On Renato Constantino: Constantino was a political historian, diplomat, college professor, museum director, and journalist who devoted much of his textual production critiquing our colonial bondage as well as the neo-imperialism of the United States of America. Gripaldo's analysis of his cultural and political philosophy is contained in the 1999 essay "Renato Constantino's Philosophy of Nationalism: a Critique." According to Gripaldo, Constantino's critique of colonialism was a twopronged project (Cf. Gripaldo, "Renato Constantino's Philosophy of Nationalism" 203). On the one hand, Constantino explored our psychological colonialism, and on the other hand, our economic colonialism, which is otherwise known as our neocolonial bondage. Psychological colonialism is manifested in our having a captive consciousness or the consciousness that is shaped by the needs and desires of the Spanish and American colonizers. Gripaldo writes:

[T] he Spanish friars saw to it that the natives, through religious conversion, became docile and illiterate, obedient and fanatical. The Americans, on the other hand, by using education with English as the medium of instruction, saw to it that the natives developed Western preferences, thereby imbibing a Western consumerist consciousness. (Gripaldo, "Renato Constantino's Philosophy of Nationalism” 204) 
Constantino imagined our psychological colonialism as a great hangover from our history of being subservient to our colonial masters.

Constantino argued that the antidote for our psychological colonialism is nationalism, which he defined as our realization that we have our own country and we, therefore, should commit to keeping it our own and develop it for our own people. He, however, warned us that there are at least four types of nationalism and that only one of them could be the proper medicine for our colonial malady (Cf. "Renato Constantino's Philosophy of Nationalism" 205-206). The first of these is the lipservice nationalism, which is unreliable and dangerous; the second is emotional nationalism that nurtures the strong sentiment for the country without necessarily understanding what nationalism really is all about; the third is intellectual nationalism that thoroughly understands what nationalism is all about, but is uncommitted to its required actions and sacrifices; while the fourth one is genuine nationalism that merges affection, understanding, commitment, and action (Gripaldo, "Renato Constantino's Philosophy of Nationalism" 206). This fourth type is the kind of nationalism that can effectively address our psychological colonialism, and this can be established and propagated through the concerted efforts of our intellectuals and through a reconceptualized nationalist educational system.

Economic colonialism, or the neocolonial colonial economic system, pertain to our economic structure that retained much of the colonial machinations of the American occupation that were geared towards the reduction of our economy to a mere appendage of the American global economy. During the American colonial period, our country acted as the supplier of raw materials to American industries and an extended market for their surplus products. Constantino argued that after the Americans left us, our colonial economy did not change much — as manifested in our mendicant policies that still focused on the export of raw materials and the import of so much manufactured goods. Even our industries are dependent on imported raw materials. These are the roots of our underdevelopment and widespread poverty. According to Gripaldo, Constantino's proposed antidote for the economic aspect of colonialism is the formulation of an economic system that takes into consideration the masses instead of merely the elite members of the society who predominantly benefited from our mendicant policies and anti-imperialist economic system (Cf. Gripaldo, “Renato Constantino's Philosophy of Nationalism” 211).

On Cirilo Bautista: Bautista is a multi-awarded poet, fictionist, critic, and literary theorist who moved to De La Salle University about the same time as Quito did. In his book Words and Battlefields: A Theoria on the Poem, he philosophized about the structure and meanings of poetry. Gripaldo's reflection on his poetics is contained in the 2002 essay "The Ideal Poem as the Rubber Tower: a Hermeneutical Analysis of Cirilo Bautista's Theory on the Poem." The term "rubber tower" pertains to Bautista's imagery of the ideal poem that looms in the consciousness of a poet during the creation process (Cf. Gripaldo, "The Ideal Poem as the Rubber Tower" 45).

Being a bilingual writer who is at home with both the Filipino and English languages, Bautista asserted that the Filipino people had already appropriated the 
English language in their project of expressing and understanding themselves as a modern Filipino people (Cf. Gripaldo, "The Ideal Poem as the Rubber Tower" 52). He saw that there was no need to suppress one language in order to cultivate the other as both can be simultaneously used to perfection. In a brew of formalism and metaphors, Bautista conceptualized the structure of a poem as composed of several layers of masks: the layer of the verb that gives the poem its intellectual direction; the layer of the adjective that imbues the poem with colors; the layer of the adverb that animates the poem's colors; and the layer of the noun that acts as the poem's fulcrum.

Bautista unbundled the meaning of a poem into three different and often competing senses. The first of these senses is the poet's intended meaning, which in its purest state would be equivalent to the meaning of the ideal rubber tower (Cf. Gripaldo, "The Ideal Poem as the Rubber Tower" 70). As this meaning is accessible only by the poet and is oftentimes ephemeral, in the sense that poets do not usually document their struggles in enfleshing their particular rubber towers, many hermeneutic and critical poststructuralist strategies would relegate this poetic meaning to the realm of the unknowable. The second of these senses is the meaning of a poem as gleaned by the reader (Gripaldo, "The Ideal Poem as the Rubber Tower" 70). This second sense is a product of the dialogue between the poem as a text and the subjectivity of the reader. This implies that there could be a multiplicity of such meanings depending on the differences in the subjectivities of the poem's readers. Finally, the third of these senses is the assumed meaning of the poem as it circulates through various readers and as it crosses through different points in time (Cf. Gripaldo, "The Ideal Poem as the Rubber Tower" 70). Hence, for Bautista, when we talk about poetic meaning, this could mean any or all of these three different senses of poetic meaning.

Despite its inner structural dynamism and multiple hermeneutic possibilities, a poem, according to Bautista, is still vulnerable to death. Bautista believed that there are two reasons why poems die. The first one is the immaturity of the poet that makes him unable to sufficiently construct his own rubber tower or to sufficiently enflesh such rubber tower with textual or aural existence (Cf. Gripaldo, "The Ideal Poem as the Rubber Tower" 92). The second one is the inferiority of the poem itself that makes such poem incapable of standing in comparison with other texts, or of validating its poetic assertion, or of adequately articulating itself (93).

\section{Critical Filipino Philosophy}

Gripaldo's critical Filipino philosophy is manifested in his critiques of the padrino system and Philippine governance, of Philippine tourism and heritage conservation, and of contemporary mass media.

On Padrino System and Philippine Governance: Gripaldo's critique of the padrino system and Philippine governance is mainly found in his 2001 essay "Cultural Traditions, the Person, and Contemporary Change: the Filipino Experience." This critique is aligned with his stand that Filipino philosophers should not stop at the profiling and articulation of the Filipino identity and cultural traits. Instead, they should 
also speculate further whether the aspects of Filipino identity or the cultural traits under scrutiny are negative or positive in relation to the holistic developmental goals of the Filipino nation, and should also exert efforts in advantageously using the positive aspects and traits as well as suppressing and rectifying the negative ones.

While other anthropologists and sociologists have already explored the negative side of the padrino system, Gripaldo made a rather broad historical study on this cultural system and demonstrated its being one of the root causes of misgovernance in the country. The padrino system is something that is related to the feudal Filipino patronage system where the landlord acts as the patron to his tenants, as well as to the compadrazgo system where two individuals who are not related by blood are socially bonded together as a consequence of their involvement in the rites of baptism or marriage (Cf. Gripaldo, "Cultural Traditions, the Person, and Contemporary Change" 189). In the padrino system, the superior individual may not be a landlord, just as the inferior individual may not be a tenant, for the system can exist outside the feudal context. In the padrino system, the social bond may not be a result of a baptismal or a wedding rite, for the system can transcend the more traditional compadrazgo context. The dominant feature of the padrino system appears to be the mutual and symbiotic commitment between a more powerful and a less powerful individual. The more powerful individual is called padrino.

Gripaldo argued that the padrino system is one of the root causes of our misgovernance and rampant corruption in the sense that it engenders nepotism when the padrino places his protégé in an otherwise meritocratic position, and in the sense that it leads to other forms of corrupt practices when the padrino expects his protégé to reciprocate his initial placement with honest or dishonest favors. Gripaldo writes:

[A] gift is given as a token of gratitude. This is followed by a second request for a favor, a third, and this time with or without a gift. But always, there is a build-up of expectation from the padrino of a reciprocal favor in the future, and sometimes this reciprocal favor may involve corrupt or unethical deed. ("Cultural Traditions, the Person, and Contemporary Change" 189)

He mentioned that this system was practiced during the Spanish period by Filipinos who wished to belong to the principalia class through the backing of Spanish officials, Spanish friars, or other principalia who happened to be favored by the Spaniards. The same practice was reinforced by the Americans. Gripaldo pointed out that Marcos and his cronies, as well as Estrada and his midnight cabinet, are but more recent manifestations of the padrino system (cf. "Cultural Traditions, the Person, and Contemporary Change" 191-193). Gripaldo, however, qualified that the padrino system may not be evil in itself and may not necessarily lead to misgovernance and corruption. He used the story of Jose Laurel as his example, who, in all practical considerations, acted as a padrino to many Filipinos who otherwise would have fallen victims to the dreaded Japanese Kempeitai (190-191). 
Gripaldo's main point in this critique of the padrino system is that although the cultural system under scrutiny may be ethically neutral in itself, in a meritocratic and bureaucratic government, or even corporate set-up, such a cultural system may no longer be fit and could only be the reason for the commission of corrupt practices. Filipinos, therefore, need to understand and be aware of this cultural system that, if left unchecked, could lead them to countless misdeeds that, in sum, would hinder their country's development.

On Philippine Tourism and Heritage Conservation: Gripaldo's critique of Philippine tourism and heritage conservation is contained in the 2005 essay "Tourism and Heritage in a Global Society: the Philippine Experience." Gripaldo started with the affirmation that tourism is good, both for the tourist and for the host country, and that heritage conservation is also good, in the sense that a heritage site needs to be appreciated by the present and the future people of a given nation. He argued that there ought to be a natural connection between tourism and heritage sites because these sites are supposed to attract tourists, and the influx of tourists could generate funds to conserve such heritage sites.

However, the Philippines seems to be a special case, because even if it boasts of five heritage sites, which are actually spread on eight locations, it lags behind the other ASEAN countries as a tourist destination (Cf. Gripaldo, "Tourism and Heritage in a Global Society" 187). Specifically, the cultural heritage sites of the Philippines are 1) its baroque churches, the Immaculate Conception Church in Intramuros, Manila; the Nuestra Senora Church in Santa Maria, Ilocos Sur; the San Agustin Church in Paoay, Ilocos Norte; and the Santo Tomas Church in Miag-ao, Iloilo; 2) the town of Vigan, Ilocos Sur; and 3) the rice terraces of Banaue, Ifugao. Meanwhile, its natural heritage sites include 4) the subterranean river of Puerto-Princesa, Palawan; and 5) the Tubbataha reefs of Palawan. Gripaldo then laid down eight reasons why the Philippines is not a favorite tourist destination in the ASEAN region.

First, he said that the heritage and tourist sites might not be well maintained such that it would be incapable of drawing enough interests locally and internationally. Second, he pointed out that the country might not be spending enough on advertising and marketing to make these heritage and tourist sites known to potential tourists. Gripaldo stressed the importance of extensive linkages with foreign travel agencies (Cf. Gripaldo, "Tourism and Heritage in a Global Society" 191). Third, our country as an archipelago is isolated from the other ASEAN countries. Although this has given us so many wonderful beaches, this has also given us a disadvantage in the sense that tourists generally prefer destinations that are linked to other destinations in other countries through the more economical bus routes or railways. Even our heritage sites have no reliable interlinking routes, thereby forcing our tourists to return to Manila before proceeding to the next heritage site.

Fourth, the professional organizations in the Philippines are not fond of hosting international conferences, which draw international participants who double as tourists during the conference breaks. Gripaldo desired that the Philosophical Association of the Philippines would one day organize an international conference, not only to let foreign philosophy scholars notice our Filipino philosophy but also to help in marketing our heritage and tourist sites. Our Department of Tourism has not thought 
of the idea yet of linking with our professional organizations. Fifth, our relatively frequent natural calamities either damage our heritage and tourist sites or periodically discourage potential tourists from coming. Sixth, the presence of transnational and huge companies near heritage and tourist sites spoils their natural purity with pollution and abrupt urbanization.

Seventh, our government is not very keen and strict in protecting our heritage and tourist sites from the ravages of infrastructural developments. Gripaldo mentioned as his example the construction of a bridge in Cagayan de Oro that damaged part of the Huluga archeological site (Cf. Gripaldo, "Tourism and Heritage in a Global Society" 192). Eighth, our peace and order situation is a little scary for potential tourists. Gripaldo laid out these eight causes not to further discourage the potential tourists but for the government and its concerned agencies, and even private individuals and corporations, to address and to rectify.

On Contemporary Mass Media: Gripaldo's take on contemporary mass media is contained in the 2005 essay "Media Powerhouse: Challenges to Contemporary Philosophers." Gripaldo initially clarified that by "media," he meant media for transportation and communication, which cover both their aboriginal, traditional, and modern modes. However, as his essay progressed, he narrowed down his focus to modern mass media (Cf. Gripaldo, "Media Powerhouse" 172-174).

Gripaldo started his critique with the identification of the tremendous powers of the contemporary mass media, and this is the reason why he used the phrase "media powerhouse" in the title of his essay. The first of these powers is their awesome speed that is made possible by the developments from science and technology (Cf. Gripaldo, "Media Powerhouse" 175-176). The second of these powers is the capacity of these modern media to subtly propagate their ideology through their recurrent and farreaching circulation of messages, sounds, and images (177). The third of these powers is closely related to the second and pertains to the capacity of these modern media to equally subtly propagate their national, cultural, and ethnic epistemes (178-180). It seems that Gripaldo anchored his distinction between ideology and episteme on the difference between the politico-economic principles and cultural worldviews of any given human collectivity. For him, the former is the basis for ideology, while the latter is the basis for episteme. The fourth of these powers is the convincing facility of these media to interpret the world, or any aspects of it, for their recipients (180-181). The fifth and the last power of the modern media that Gripaldo identified is their ability to dish out relative meaning (181-183). This pertains to the covert control of modern media in creating meaning by manipulating the contexts and connotations of their messages, sounds, and images.

Gripaldo's identification of these powers came with the unveiling of their hidden threats to man, nations, cultures, and ethnicities, as well as with his subsequent challenge to other contemporary philosophers to further explore these dangers and come up with viable recommendations and solutions. He pointed out that the awesome speed of modern media can potentially fragment our values and persons. He invited other philosophers to ponder not only on "the importance of technological speed," but also on how "to strike a balance between the slow and the rapid in order to arrive at just the right speed to ensure one's efficiency in a rapidly changing society" (Cf. 
Gripaldo, "Media Powerhouse" 183-184). He explained that the ideological power of modern media would not only compromise truth but it would also imprison their recipients within the ideological frames of the controllers of such media. He encouraged other philosophers to effectively educate the people on how to "temporarily distance ... (themselves) in order to objectively uncover, evaluate, or critique the presupposed ideological content of a message relayed through the new media prior to its acceptance or rejection" (184).

Gripaldo demonstrated that the epistemic power of the modern media could obliterate national, cultural, and ethnic diversity as the hegemonic epistemes of the controllers of the modern media are propagated. He advised the other philosophers on finding ways and means on how to "enlighten local, national, and world leaders to respect and uphold the different tribal and national epistemes of different countries in order to preserve national integrity; unless, of course, a danger or threat from a country's episteme is imminent to the world-at-large" (Cf. Gripaldo, "Media Powerhouse" 184). Gripaldo revealed that the power of the modern media to interpret the world actually meant the multiplication of different interpretations of the world, which in the end would create nihilism among their recipients. Thus, he enjoined the other philosophers to reject "the prejudice of nihilistic perspectivism" while arguing that "even if all is interpretation, there is evidence of inter-subjective truth and an intersubjective knowledge for a given period of time in a given historical setting" (184). Lastly, he pointed out that the power of modern media to dish out the relative meaning by manipulating the contexts and connotations of their messages, sounds, and images is already self-evident to be threatening and dangerous to their recipients. $\mathrm{He}$ explained to other philosophers:

[T] he challenge lies in the recognition that technological advances in new media and in other aspects of post-industrial society, wherein human beings are the beneficiaries, cannot guarantee human happiness and, thus, must raise again the existential issue as to what it truly means to live. (184)

\section{Filipino Philosophy as Revisionist Writing}

Gripaldo attempted to contribute something in the very seldom taken pathway of Filipino philosophy as revisionist writing. However, instead of mastering a particular thinker and subsequently surpassing him/her, he opted to work with philosophical concepts and theories. Hence, this subsection will explore Gripaldo's take on the public good and his proposed circumstantialist moral theory.

On Public Good: The concept of the public good has already been exhaustively discussed in the context of politics and economics. Gripaldo attempted to reconstruct this same concept within the context of politics and ethics with the intention of using it later on as a heuristic device in analyzing public evils such as corruption, pollution, and crimes. His politico-economic take on public good is contained in the 2006 essay "The Concept of the Public Good: a View from a Filipino Philosopher." 
Gripaldo started with the widely accepted politico-economic definition of public good as a non-rivalrous and non-excludable good (Cf. Gripaldo, "The Concept of the Public Good" 87). Non-rivalry refers to the criterion that whenever somebody uses such good, it would not diminish or exhaust the same good, while non-excludability refers to the criterion that the access and use of such good are open to all individuals. Upon this common understanding, he proceeded to introduce three nuances, the first one of which is his constriction of the range of his public by limiting it to communal and national publics (83). His second nuance is his elaboration of the goodness of the public good based on its desirability and beneficial impact on the communal and national public (83). His third nuance is his introduction of the distinction among public public goods, private public goods, and mixed public goods. By public public goods, Gripaldo meant those public goods that are made available to the communal and national publics either from nature or from the government, whereas private pubic goods are those public goods that are made available to the communal and national public through the efforts of the private sector. Lastly, the mixed public goods are those public goods that are similar to public public goods but are made available to the communal and national publics through the efforts of some private organizations that are disinterested in profit-making (91-94).

After laying down his politico-ethical construct of public good, Gripaldo revealed at least four important implications, the first one of which is that the private sector may provide public goods for the reason that it may indirectly profit from them (Cf. Gripaldo, "The Concept of the Public Good" 95-96). A mall owner, for example, may organize a free concert with a long-term goal of making his mall more popular to his possible clientele. The second implication, according to Gripaldo, is that the government should provide public goods based on its obligation for social service. The third implication, which is intimately related to the second implication, is that when a government provides public goods based on purely electoral reasons (as a means for political leaders to gain favorable votes in the next elections), such government exposes itself to the possibility of dishing out only an apparent public good (96-97). The fourth implication, according to Gripaldo, is that in the case of the inability of a given government to provide some public goods, it is still possible for some private organizations, or groups of individuals, to band together and pool their resources in order to be able to come up with such needed public goods.

A Circumstantialist Moral Theory: Gripaldo's attempt to construct his own moral theory is found in the essays "Freedom to Choose: an Essay on Situational Determinism" (2003) and "He could have Chosen Otherwise?" (1977) which are both based on his 1977 book Circumstantialism. He started his formulation with a distinction on the two different meanings of circumstance: the first one of which refers to a totalized situation in which the moral agent is compelled by his own context to act in a certain way; while the second meaning refers to a situational condition which gives enough room for the moral agent to make a rational choice on what he is going to do (Cf. Gripaldo, "Freedom to Choose" 144). Gripaldo founded his circumstantial moral theory on the second meaning of circumstance that allows the possibility of making authentic rational choices. 
To emphasize his focus on the authenticity of rational choices/decisions/actions, he adapted T. F. Daveney's five conditions for these choices/decisions/actions to be authentic. Gripaldo writes:

First, there must be genuine alternatives. Second, the chooser must be aware of these alternatives. Third, he must believe that these alternatives are attainable or doable. Fourth, he must have a prior aim, purpose, or want for choosing. And fifth, the alternative chosen must be that one which suits him best. ("Freedom to Choose" 147)

Gripaldo proceeded to outline his conceptualization of the process of choosing/deciding, which he partitioned into three stages. The first stage pertains to the moral agent's recognition of the alternatives that are in front of him. This is followed by the second stage, which pertains to the moral agent's weighing of the "merits and demerits, advantages and disadvantages, pluses and minuses of each alternative" (Gripaldo, "Freedom to Choose" 150). Finally, Gripaldo's process of choosing/deciding is capped by the third stage, which pertains to "the level or phase where the agent acts out his/her decision/choice," or more simply, to the full consummation of the choosing/deciding process (Gripaldo, "Freedom to Choose" 150).

Gripaldo pointed out that during the second stage of the choosing/deciding process, the situational conditions, or the circumstances of the moral agent, would start to determine his weighing of the pros and cons of the alternatives available to him. He grouped these situational conditions into four: “[T]he person's present external environment (Source1), the person's past (Source2), the person's future (Source3), and the person's present physical and mental condition (Source4)" (Gripaldo, "Freedom to Choose" 150). He further explained that some of these specific situational conditions may or may not be directly present in the moral agent's consciousness at the time of his choosing/deciding. Gripaldo emphasized that because each individual person is unique and because the configuration of situational conditions that surround him is unique at every point in time, each choosing/deciding situation is, therefore, unique (Gripaldo, "Freedom to Choose" 154).

Although Gripaldo's circumstantialist construction of the moral choice/decision demonstrated how choices/decisions are determined by the moral agent's environmental (Source1), historical (Source2), futural/intentional (Source3), and physical/mental (Source4) conditions, he maintained that the moral agent's choice/decision is a product of human freedom. In this sense, Gripaldo can be grouped with the other moral theorists who believed in the compatibility of freedom and determinism. He believed that the moral agent is free as he goes through all the three stages of the process of choosing/deciding (Cf. Gripaldo, "Freedom to Choose" 156157).

Finally, Gripaldo revealed the five corollaries of his circumstantialist moral theory. Firstly, the feeling of remorse has no part in his rational ethics as he is in favor of adopting a stoic attitude towards past mistakes that prioritizes the making of amends in order to rectify a situation (Cf. Gripaldo, "Freedom to Choose" 159). Secondly, a 
moral agent should not think of his alternatives always in terms of black and white because there are instances that such an agent can take more than one alternative (159). Thirdly, a moral agent should try to broaden his awareness of the situational conditions circumscribing him in order to assure more reliable decision-making (159-160). Fourthly, the understanding of the process of decision-making should make us deemphasize the punitive aspects of moral formation and instead put more importance on the incentive aspects of moral formation (160). Fifthly, an awareness of the process of decision-making should also make us conscious of the struggle involved in controlling our passion so as to make our choices/decisions more rational (160).

\section{CONCLUSION}

Quito's diagnosis of the underdevelopment of Filipino philosophy might be the most comprehensive and incisive so far (Demeterio 2020). However, Gripaldo managed to add significant insights to this. Specifically, his third, fourth, and sixth elements and factors that hindered the development of Filipino philosophy are very remarkable. His third and fourth elements and factors are about our failure to appropriate western philosophical traditions and make them serve our own concerns and problems. His sixth element and factor are about our failure to have a unified philosophical organization that would make our otherwise fragmented organizations communicate with each other and move together. Before Gripaldo retired from DLSU, he was elected to the Board of the Philosophical Association of the Philippines, and he really tried to push for the federalization of the various philosophical organizations in the country. However, he made a strategic mistake in trying to lobby for the Philosophical Association of the Philippines as the umbrella organization, which the other philosophical organizations detested. Although his initial lobbying fizzled out, a few months after his death, these philosophical organizations decided to form a federation that is now known as the Union of Societies and Associations of Philosophy in the Philippines. At this point, we can only hope that indeed this new federation would more powerfully work for the development of Filipino philosophy. Gripaldo's critique on Filipino philosophy as an interpretation of the Filipino worldview and identity constitutes a powerful guideline that could strengthen the agenda of those younger scholars who intend to focus on this area of philosophizing. He stressed that Filipino scholars who desire to work within this philosophical parameter should not stop with the mere articulation and description of the Filipino folkways and mores, but should exert further efforts in making their findings useful and in critiquing and rectifying whatever folkways and mores they have established to be counterproductive and questionable.

The bulk of Gripaldo's contributions to Filipino philosophy is found in his studies on the philosophical insights of some Filipino intellectuals. In fact, this paper is a tribute to Gripaldo's project of studying Filipino intellectuals and philosophes. This preoccupation is consistent with his agenda of proving that there is indeed a Filipino philosophy in the traditional sense of the word. By articulating these philosophical vignettes, he connects his readers to the philosophical themes and 
concerns that creatively perplexed the Filipinos. Thus, Filipino philosophy scholars may revisit and critique these implicit vignettes or address these themes and concerns using more explicit philosophical frameworks. His works on the philosophical insights of some Filipino intellectuals do not only constitute ready-to-use materials for the teaching of Filipino philosophy but could serve as catalysts for the further development of Filipino philosophy. These materials can pull Western philosophical traditions nearer towards the concerns and problems of Filipinos as a people.

Like the other pioneering Filipino philosophers of De La Salle University, Quito, Abulad, Ceniza, and Timbreza, Gripaldo's critical reflections on Philippine culture and politics are not framed using any of the Marxist-inspired frameworks, yet his training as a historian equipped him with a sharp critic's eye for details and a broad context for the reliable appraisal of his subject matter (Demeterio, "The Intellectual Heritage of the Pioneering Lasallian Filipino Philosophers" n.d.). Many of the Filipino luminaries he studied are themselves involved in critical Filipino philosophy, such as Rizal, Bonifacio, Quezon, and Constantino. There is an overlap between Gripaldo's engagement with the Filipino luminaries and his engagement with Filipino philosophy.

Among the known pioneers of Filipino philosophy, it is most probably Gripaldo who is the most self-conscious in positioning himself as a Filipino philosopher (Demeterio, "The Intellectual Heritage of the Pioneering Lasallian Filipino Philosophers" n.d.). Thus, he ventured into the very rarely taken path of revisionist writing and presented his reconceptualization of the public good and his proposed circumstantialist moral theory. He was the one who pointed out that the path of revisionist writing is one of the discourses of Filipino philosophy, and he may be the one also who is actually leading us the way in this very difficult and challenging path of philosophizing. We might not all be convinced about the originality of his thoughts, but his courage and determination to transcend philosophizing as mere commenting on western philosophical texts are worth emulating for all Filipino scholars of philosophy.

Looking at Gripaldo side by side with the other pioneering Filipino Lasallian philosophers, we can say that he is closer to Timbreza both for being locally educated and for having been trained in social sciences at the University of the Philippines (Demeterio, "The Intellectual Heritage of the Pioneering Lasallian Filipino Philosophers" n.d.). However, because the Philosophy Department of the University of the Philippines leans more towards Anglo-Saxon philosophies, Gripaldo is also close to Claro Ceniza, even though the former's works in the area of logical analysis were not reflected in his texts covered by this paper (Demeterio, "The Intellectual Heritage of the Pioneering Lasallian Filipino Philosophers" n.d.). Among the other four Lasallian philosophers, Gripaldo admired Ceniza the most and even called him a "neo-Parmenidean philosopher" (Gripaldo, "Ceniza the Neo-Parmenidean: a Critique of his Metaphysics."). Unlike Quito and Timbreza, both of whom started with the premise that Filipino philosophy as such is hardly existent and so they had to scrounge philosophical elements from folklore and folkways, Gripaldo took the pathway similar to that of Ceniza as they were both guided by the conviction that Filipino philosophy exists (Demeterio, "The Intellectual Heritage of the Pioneering Lasallian Filipino Philosophers" n.d.). However, whereas Ceniza simply did not philosophize and problematize the Filipinoness of his philosophy, Gripaldo invested much effort in 
proving that philosophy as such implicitly existed in the discourses of a number of Filipino intellectuals and at the same time philosophized with the consciousness that he is philosophizing as a Filipino thinker (Demeterio, "The Intellectual Heritage of the Pioneering Lasallian Filipino Philosophers" n.d.).

Because of some intramural "political" differences with his former colleagues at the De La Salle University, Gripaldo endured some form of ostracism from the Philosophy Department that he previously chaired. No one can deny that his dedication to the development of Filipino philosophy could easily equal, if not surpass, those of Quito, Abulad, or Timbreza. Gripaldo is the thinker who insisted that there is such a thing as Filipino philosophy in the strict sense of the word "philosophy." He invited other scholars to look, be inspired with, and be enriched by this philosophy in the textual production of some Filipino intellectuals, and he invited other scholars as well to be bold enough to philosophize as Filipino thinkers. For good or for bad, he decided to devote his post-retirement time and energy to the management of the Philippine National Philosophical Research Society with the hope of strengthening the bond of cooperation among Filipino philosophers and scholars in philosophy until his death in 2017.

\section{REFERENCES}

Demeterio, F.P.A. 2020. A critical reflection on my reading and re-reading of Emerita Quito's thoughts on the underdevelopment and hope for the development of Filipino philosophy. Philosophia: International journal of philosophy 21 (2): 169-186.

Demeterio, F.P.A. 2014a. Assessing the developmental potentials of some twelve discourses of Filipino philosophy. Philippiniana Sacra 49 (147): 189-230.

Demeterio, F.P.A. 2014b. Quito, Ceniza, Timbreza, Gripaldo: DLSU professors' contributions to Filipino philosophy. Philosophia: International journal of philosophy 15 (2): 180-208.

Demeterio, F.P.A. 2013. Status of and directions for Filipino philosophy in Zialcita, Timbreza, Quito, Abulad, Mabaquiao, Gripaldo, and Co. Philosophia: International journal of philosophy 14 (2): 186-215.

Demeterio, F.P.A. N.d. "The intellectual heritage of the pioneering Lasallian Filipino philosophers." Unpublished book manuscript.

Gripaldo, Rolando. 2009. Agnostic deism: Rizal's religious philosophy. Filipino philosophy: Traditional approach. Pt. I, Sec. 2. Quezon City: C \& E. 33-56.

Gripaldo, Rolando. 2009. Bonifacio and Jacinto: Two philosophies of revolution and their sources. Filipino philosophy: Traditional approach. Pt. I, Sec. 2. Quezon City: C \& E. 97-112.

Gripaldo, Rolando. 2009. Bonifacio, the translator: A critique. Filipino philosophy: Traditional approach. Pt. I, Sec. 2. Quezon City: C \& E. 57-71.

Gripaldo, Rolando. 2009. Ceniza the neo-Parmenidean: A Critique of his metaphysics. Filipino philosophy: Traditional approach. Pt. I, Sec. 2. Quezon City: C \& E. 105-143. 
Gripaldo, Rolando. 2009. Cultural approach to Filipino philosophy. Filipino philosophy: Traditional approach. Pt. I, Sec. 2. Quezon City: C \& E. 198-206.

Gripaldo, Rolando. 2009. Cultural traditions, the person, and contemporary change: The Filipino experience. Filipino philosophy: Traditional approach. Pt. I, Sec. 2. Quezon City: C \& E. 207-228.

Gripaldo, Rolando. 2009. Filipino philosophy, western tradition, and nation building. The making of a Filipino philosopher and other essays. Mandaluyong City: National Bookstore. 41-61.

Gripaldo, Rolando. 2009. Filipino philosophy: A western tradition in an eastern setting. The making of a Filipino philosopher and other essays. Mandaluyong City: National Bookstore. 10-40.

Gripaldo, Rolando. 2009. Freedom and futurism in art: A critique of embuscado's aesthetics of dissectionism. Filipino philosophy: Traditional approach. Pt. I, Sec. 2. Quezon City: C \& E. 6-43.

Gripaldo, Rolando. 2009. Freedom to choose: An essay on situational determinism." Filipino philosophy: Traditional approach. Pt. I, Sec. 2. Quezon City: C \& E. 144-163.

Gripaldo, Rolando. 2009. He could have chosen otherwise? Filipino philosophy: Traditional approach. Pt. I, Sec. 2. Quezon City: C \& E. 164-171.

Gripaldo, Rolando. 2009. Is there a Filipino philosophy? The making of a Filipino philosopher and other essays. Mandaluyong City: National Bookstore. 1-9.

Gripaldo, Rolando. 2009. Jacinto's libertarian philosophy of revolution. Filipino philosophy: Traditional approach. Pt. I, Sec. 2. Quezon City: C \& E. 80-96.

Gripaldo, Rolando. 2009. Laurel: The political philosopher and the man." Filipino philosophy: Traditional approach. Pt. I, Sec. 2. Quezon City: C \& E. 173-201.

Gripaldo, Rolando. 2001. Liberty and love: The political and ethical philosophy of Emilio Jacinto. Manila: De La Salle University Press.

Gripaldo, Rolando. 2009. Media powerhouse: Challenges to contemporary philosophers." Filipino philosophy: Traditional approach. Pt. I, Sec. 2. Quezon City: C \& E. 172-184.

Gripaldo, Rolando. 1994. Presidential succession of 1943. Quezon-Winslow correspondence and other essays. Manila: De La Salle University Press. 189205.

Gripaldo, Rolando. 1994. Quezon and Osmena on the Hare-Hawes-Cutting and Tydings-McDuffie acts. Quezon-Winslow correspondence and other essays. Manila: De La Salle University Press. 97-118.

Gripaldo, Rolando. 1994. Quezon and the Fairfield project. Quezon-Winslow correspondence and other essays. Manila: De La Salle University Press. 87-96.

Gripaldo, Rolando. 1994. Quezon on the dominion status for the Philippines. QuezonWinslow correspondence and other essays. Manila: De La Salle University Press. 119-129.

Gripaldo, Rolando. 1994. Quezon on the question of reelection. Quezon-Winslow correspondence and other essays. Manila: De La Salle University Press. 175188. 
Gripaldo, Rolando. 1994. Quezon's partyless democracy. Quezon-Winslow correspondence and other essays. Manila: De La Salle University Press. 155163.

Gripaldo, Rolando. 2009. Quezon's philosophy of Philippine education. Filipino philosophy: Traditional approach. Pt. I, Sec. 2. Quezon City: C \& E. 164-172.

Gripaldo, Rolando. 1994. Quezon's political and social thought: A dissertation Resume." Quezon-Winslow correspondence and other essays. Manila: De La Salle University Press. 207-213.

Gripaldo, Rolando. 2009. Quezon's political philosophy. Filipino philosophy: Traditional approach. Pt. I, Sec. 2. Quezon City: C \& E. 113-141.

Gripaldo, Rolando. 2009. Reflections of Bonifacio's philosophy of revolution. Filipino philosophy: Traditional approach. Pt. I, Sec. 2. Quezon City: C \& E. 72-79.

Gripaldo, Rolando. 2009. Renato Constantino's philosophy of nationalism: A critique.” Filipino philosophy: Traditional approach. Pt. I, Sec. 2. Quezon City: C \& E. 202-220.

Gripaldo, Rolando. 2009. Rizal's philosophy of nonviolence. Filipino philosophy: Traditional approach. Pt. I, Sec. 2. Quezon City: C \& E. 7-17.

Gripaldo, Rolando. 2009. Rizal's utopian society. Filipino philosophy: Traditional approach. Pt. I, Sec. 2. Quezon City: C \& E. 18-32.

Gripaldo, Rolando. 2009. Social justice: Cornerstone of Quezon's social thought. Filipino philosophy: Traditional approach. Pt. I, Sec. 2. Quezon City: C \& E. 142-163.

Gripaldo, Rolando. 2009. The concept of the public Good: A view from a Filipino philosopher. The making of a Filipino philosopher and other essays. Mandaluyong City: National Bookstore. 82-103.

Gripaldo, Rolando. 2009. The ideal poem as the rubber tower: A hermeneutical analysis of Cirilo Bautista's theory on the poem. Filipino philosophy: Traditional approach. Pt. I, Sec. 2. Quezon City: C \& E. 44-104.

Gripaldo, Rolando. 2009. The making of a Filipino philosopher. The making of a Filipino philosopher and other essays. Mandaluyong City: National Bookstore. 62-81.

Gripaldo, Rolando. 2009. The person as individual and social being. Filipino philosophy: Traditional approach. Pt. I, Sec. 2. Quezon City: C \& E. 229-234.

Gripaldo, Rolando. 2009. The person, the nation and the world: Cooperative choice in a globalizing situation. Filipino philosophy: Traditional approach. Pt. I, Sec. 2. Rolando Gripaldo. Quezon City: C \& E. 235-251.

Gripaldo, Rolando. 1994. The Quezon-Osmena split of 1922. Quezon-Winslow correspondence and other essays. Manila: De La Salle University Press. 39-58.

Gripaldo, Rolando. 1994. The Quezon-Winslow correspondence: A friendship turned sour. Quezon-Winslow correspondence and other essays. Manila: De La Salle University Press. 1-37.

Gripaldo, Rolando. 1994. The Quezon-Wood controversy. Quezon-Winslow correspondence and other essays. Manila: De La Salle University Press. 59-85. 
Gripaldo, Rolando. 2009. Tourism and heritage in a global society: The Philippine experience. Filipino philosophy: Traditional approach. Pt. I, Sec. 2. Quezon City: C \& E. 185-197.

Joaquin, Jeremiah Joven. 2010. Gripaldo and Mabaquiao on Filipino philosophy: A critical assessment of two attempts to establish a Filipino philosophy. Dalumat E-journal. 1 (1): 121-129.

Liwanag, Leslie Anne. 2016. Ang pilosopiya ni Emerita S. Quito. Kritike: An online journal of philosophy. 10 (1): 54-82.

Rosario, Tomas. 2000. Foreword to the second edition. Filipino philosophy: A critical bibliography, 1774-1997. $2^{\text {nd }}$ ed. Rolando Gripaldo. Manila: De La Salle University Pres. iii-iv. 